Abstracta Iranicacta Iranica

Revue bibliographique pour le domaine irano-aryen

Volume 32-33 | 2013

Comptes rendus des publications de 2009-2010

\title{
Michael G. Morony. Should Sasanian Iran be Included in Late Antiquity?
}

\section{Rika Gyselen}

\section{Q OpenEdition}

1 Journals

Édition électronique

URL : http://journals.openedition.org/abstractairanica/40560

DOI : 10.4000/abstractairanica.40560

ISSN : 1961-960X

\section{Éditeur :}

CNRS (UMR 7528 Mondes iraniens et indiens), Éditions de l'IFRI

\section{Édition imprimée}

Date de publication : 1 décembre 2013

ISSN : 0240-8910

\section{Référence électronique}

Rika Gyselen, « Michael G. Morony. Should Sasanian Iran be Included in Late Antiquity? », Abstracta Iranica [En ligne], Volume 32-33 | 2013, document 191, mis en ligne le 01 juillet 2016, consulté le 26 septembre 2020. URL : http://journals.openedition.org/abstractairanica/40560 ; DOI : https://doi.org/ 10.4000/abstractairanica.40560

Ce document a été généré automatiquement le 26 septembre 2020.

Tous droits réservés 


\title{
Michael G. Morony. Should Sasanian Iran be Included in Late Antiquity?
}

\author{
Rika Gyselen
}

\section{RÉFÉRENCE}

Michael G. Morony. Should Sasanian Iran be Included in Late Antiquity? 2010, 9 p. [Sasanika Occasional Papers, I]

1 L'A. se demande si l'Iran sassanide devrait être inclus dans (l'histoire de) l'Antiquité tardive, comme le font certains ouvrages alors qu'une telle inclusion est contestée par ceux qui définissent 'l'antiquité tardive' selon des critères exclusivement romains.

2 Comme le concept 'antiquité tardive' n'est après tout qu'une construction intellectuelle, l'A. se demande pourquoi on ne pourrait pas tout simplement la définir par un critère chronologique (III ${ }^{\mathrm{e}}-\mathrm{VII}{ }^{\mathrm{e}}$ siècles A.D.). En outre l'association de l'Iran sassanide au monde de l'antiquité tardive se justifie par de nombreuses similarités dont dix-sept sont commentées - avec le monde romain.

\section{AUTEURS}

RIKA GYSELEN

CNRS, Mondes iranien et indien, Paris 